DOI: $10.22363 / 2313-1683-2018-15-3-364-367$

УДК 159.99

\title{
ERASMUS+ INTERNATIONAL STAFF EXCHANGE WEEK IN VILNIUS
}

\author{
Olga V. Maslova \\ Peoples' Friendship University of Russia (RUDN University) \\ 6, Miklukho-Maklaya str., Moscow, 117198, Russian Federation

\section{МЕЖДУНАРОДНАЯ НЕДЕЛЯ ОБМЕНА ОПЫТОМ ПО ПРОГРAMME ERASMUS+}

\author{
О.В. Маслова \\ Российский университет дружбы народов \\ Российская Федерация, 117198, Москва, Миклухо-Маклая ул., 6
}

Erasmus+ is a European Union (EU) program, aimed at supporting the cooperation in the field of education, vocational training, youth and sport for the period from 2014 to 2020. The name of the program comes from the name of the Dutch philosopher Erasmus of Rotterdam, a well-known opponent of dogmatism, who lived and worked in many countries in Europe to broaden his horizons and acquire new knowledge. Within the framework of Erasmus + the following main areas are identified: Key Action 1: Learning Mobility of Individuals - new possibilities for mobility for students and teachers; Key Action 2: Cooperation for innovation and good practice - cooperation for the development of the capacity of universities and the exchange of best practices.

Erasmus + Staff Exchange Week took place 2-6 July 2018 at Mykolas Romeris University (MRU) in Vilnius. There were university staff from 23 MRU partner institutions taking part in the Staff Exchange Week that represented Armenia, Azerbaijan, Canada, Greece, Italy, Japan, Hungary, Malaysia, Indonesia, Russia, Slovenia, Spain, Taiwan, Turkey and Uzbekistan (Fig. 1). For example, Miyuki Arai, Project Manager-International Mobility of Saint Mary's University (Canada); Darja Rabzelj, Head of International relations Office of University of Ljubljana (Slovenia); Alberto Spadoni, employee of Administrative and managerial Postgraduate education office University of Genoa (Italy); Cristina Bibian Mateo, librarian of University Barselona (Spain); Pascale Srulovici, Head of International Relations Office of Aix Marseille University (France); Yusuke Miyashita, employee of Office of the President of Kanagava University (Japan); Rita Wan-Chin Li, 
coordinator for governmental scholarships of Office of International Cooperation of National Chengchi University (Taiwan). The RUDN University was represented by Olga V. Maslova, Ph.D., Associate Professor of the Department of Social and Differential Psychology. She emphasized the peculiarity of RUDN University as an internationally oriented University and noted the interest in scientific cooperation and holding joint psychological research.

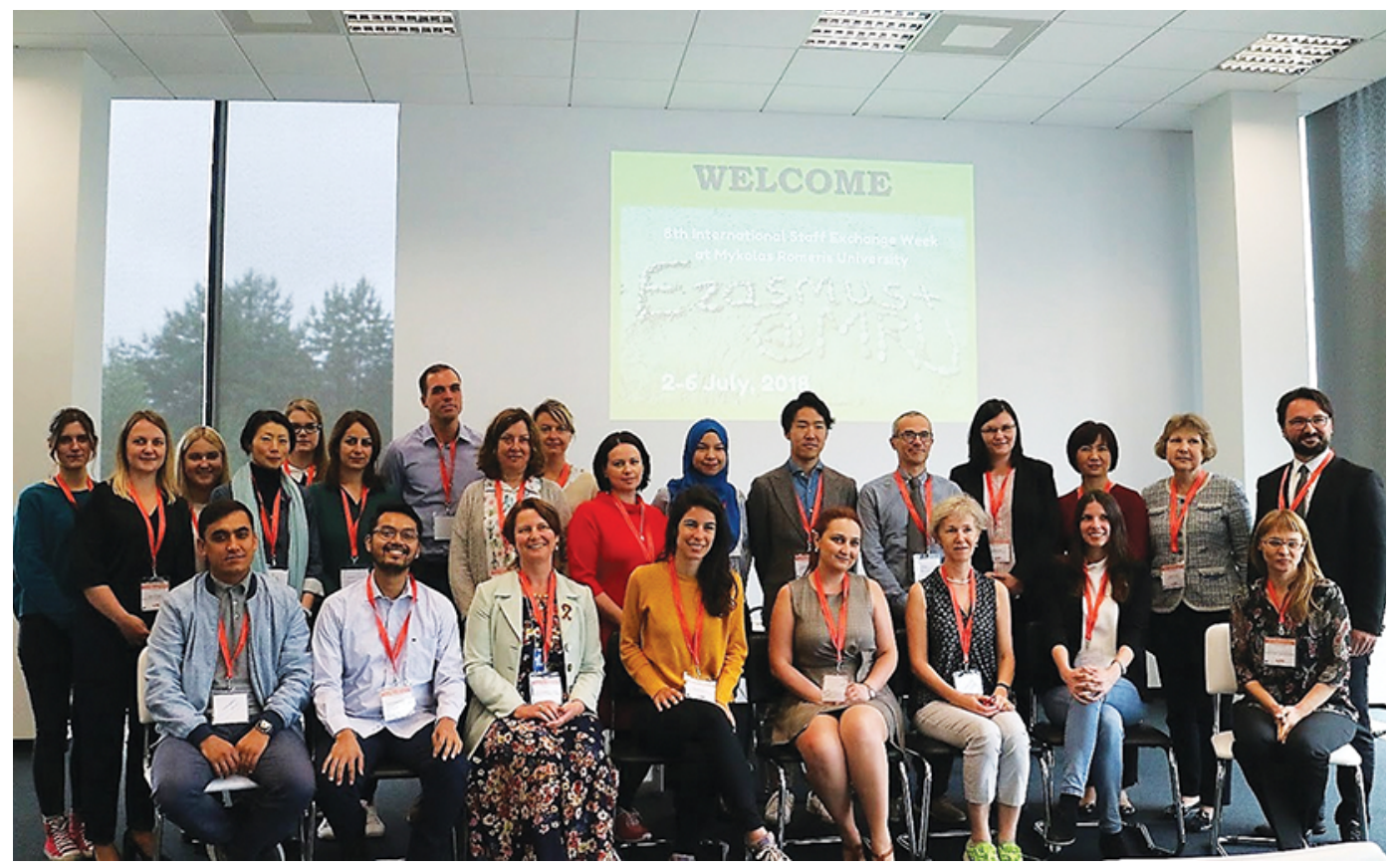

Fig. 1. Participants of the Erasmus+ International Staff Exchange Week at MRU

The main objective of the International Staff Exchange Week was to widen and strengthen cooperation, exchange know-how, good experiences and practices in the areas of interest to the participants. The participants had the opportunity to get acquainted with the work of the MRU's International Office, Academic Affairs Centre, Research and Innovation Support Centre and the MRU Library. The participants also visited the MRU Faculties and institutes such as Faculty of Economics and Business, Faculty of Law, Faculty of Public Governance, Institute of Humanities (Fig. 2), Institute of Psychology, Institute of Communication, Institute of Educational Sciences and Social Work.

In the framework of the Exchange Week, the Director of the Institute of Psychology of the MRU Associate Professor Antanas Valantinas and Deputy Director of the Institute of Psychology of the MRU Professor Rasa Pilkauskaite Valickiene met with Olga V. Maslova (Fig. 3). During the meeting they reviewed the research areas of the MRU Institute of Psychology and the RUDN Department of Social and Differential Psychology of University. The colleagues found the points of mutual interest, discussed the possible forms of scientific cooperation and partnerships in the field of psychological research, the issues of Mobility of students and teachers, and the possibility of signing a cooperation agreement at the level of faculties (institutions). 


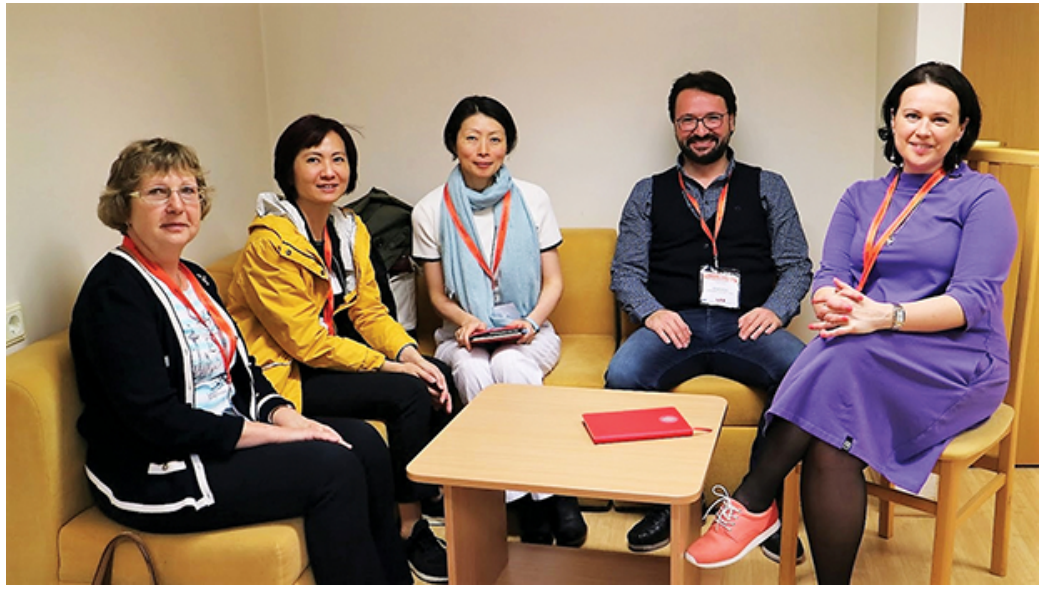

Fig. 2. The meeting with the Director of the Institute of Humanities of MRU, Associate Professor Liudmila Mockiene (the first right). Further: Associate Professor Oktay Sahbaz, Dumlupinar university (Turkey); Project Manager of International Mobility Miyuki Arai, Saint Mary University (Canada), coordinator for governmental scholarships Rita Wan-Chin Li, National Chengchi University (Taiwan), Associate Professor Olga Maslova, RUDN

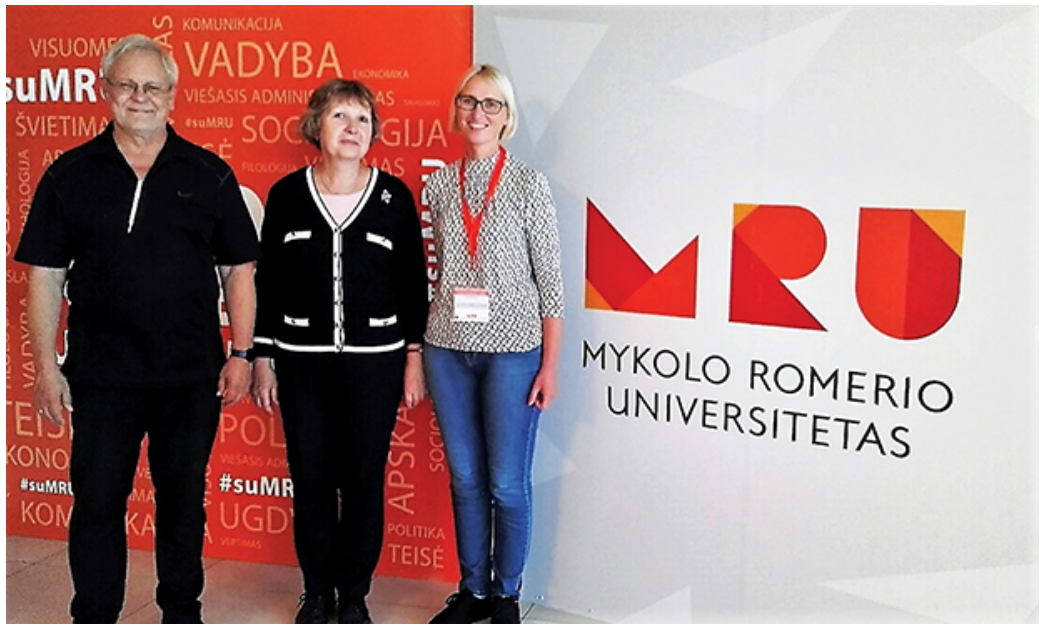

Fig. 3. Director of the Institute of Psychology of the MRU Associate Professor Antanas Valantinas, Associate Professor-researcher of the Department of social and differential psychology RUDN Olga Maslova and Deputy Director of the Institute of Psychology of the MRU Professor Rasa Pilkauskaite Valickiene

The Staff Exchange Week took place during Lithuania's Centennial Year, marking 100 years since the Restoration of Lithuania's Independence. The participants of the Exchange Week had the opportunity to visit the unique Lithuanian Song Festival, dedicated to the centenary anniversary of the restoration and even take part in the Procession of the Song and dance celebration's participants from the Cathedral Square to Vingis Park. The Procession was one of the most colourful, joyful, vital events of the celebration. This was a real singing and dancing human river (Fig. 4). This year, the program was attended by over 40000 participants. People from all over Lithuania gathered in Vilnius to share songs, dances and traditions of their region. It is a phenomenal event entered in the list of the masterpieces of the oral and intangible heritage of humanity by the UNESCO. 


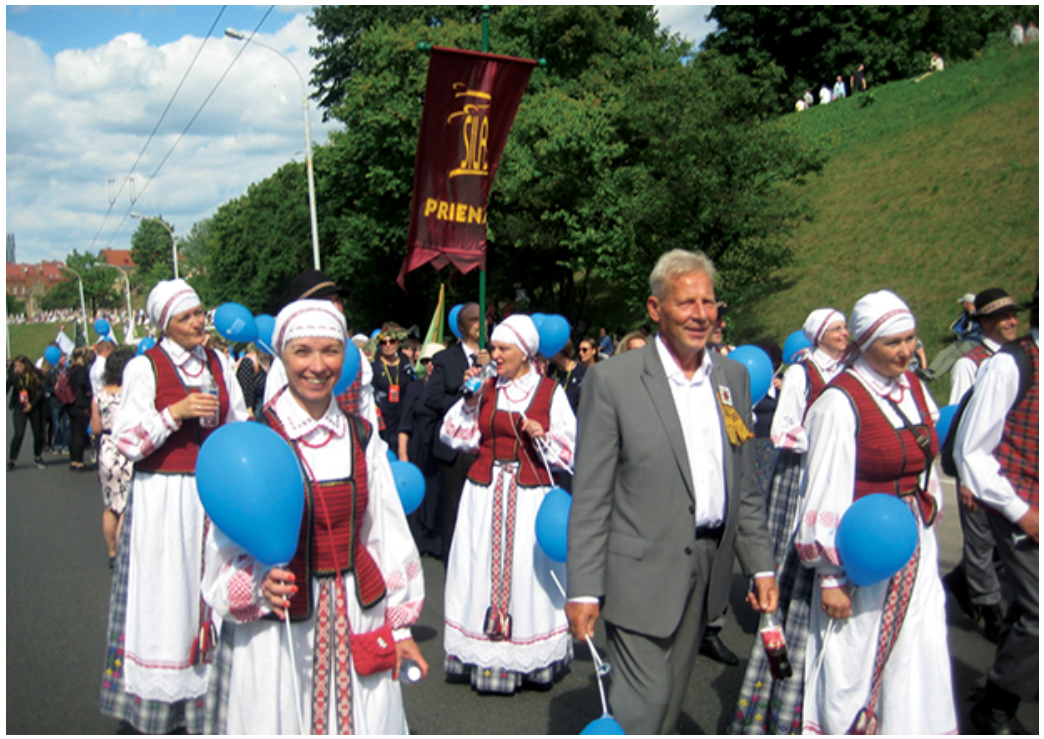

Fig. 4. Procession from the Cathedral Square to Vingis Park. In the photo there are residents of Prienai, where in 1900 the famous psychologist Bluma V. Zeigarnik was born

Erasmus+ International Staff Exchange Week at Mykolas Romeris University promoted widening and strengthening cooperation and partnerships, sharing experience. Saying goodbye, the participants spoke about the future joint projects in different spheres. Erasmus + really opens up new horizons - geographical, cultural, professional, personal.

(C) Maslova O.V., 2018

\section{For citation:}

Maslova, O.V. Erasmus+ International Staff Exchange Week in Vilnius. RUDN Journal of Psychology and Pedagogics, 15(3), 364-367. doi: 10.22363/2313-1683-2018-15-3-364-367

\section{Bio Note}

Olga V. Maslova - Ph.D. in Psychology, Associate Professor, Associate Professor of Social and Differential Psychology Department, Peoples' Friendship University of Russia (Moscow, Russia). E-mail: maslova_ov@rudn.university

\section{Для цитирования:}

Маслова О.В. Erasmus+ International Staff Exchange Week in Vilnius // Вестник Российского университета дружбы народов. Серия: Психология и педагогика. 2018. Т. 15. № 3. С. 364-367. doi: 10.22363/2313-1683-2018-15-3-364-367

\section{Сведения об авторе:}

Маслова Ольга Васильевна - кандидат психологических наук, доцент, доцент кафедры социальной и дифференциальной психологии РУДН. E-mail: maslova_ov@rudn.university 